Professor Robert Morris Ogden, of Cornell University, has been appointed lecturer on education at Harvard University for the second half of the academic year 1922-23.

DR. Uhlennutri, director of the Behring Institute for Experimental Therapy in Marburg, has received a call to the chair of hygiene in Bonn, as the successor of Professor Neumann, who has accepted the position left vacant in Hamburg by the death of Professor Dunbar.

\section{DISCUSSION AND CORRESPOND- ENCE}

\section{THE PRODUCTION OF SPECIES}

To THE Editor of ScIence: It is often remarked by biologists who have never studied organisms in the field, that it is easy "to develop forms at will indistinguishable from actual species."

To my mind, this is one of the most deceptive of the anti-Darwinian heresies. A species is not merely a form or group of individuals distinguished from other groups by definable features. A complete definition involves longevity. A species is a kind of animal or plant which has run the gauntlet of the ages and persisted. Spreading across or around barriers, a species may break up into parallel or geminate species, each having run a special gauntlet of its own, its primitive qualities altering through selection, usually slowly, in the progress of the centuries. A new form inaugurated through change of surroundings, through persistent selection and segregation, or through hybridization, is not a "species" until it ean hold its own with the rest. None of the created "new species" of plant or animal I know of would last five years in the open, nor is there the slightest evidence that any new species of field or forest or ocean ever originated from mutation, discontinuous variation or hybridization.

Garden or greenhouse products are immensely interesting and instructive, but they throw little light on the origin of species. To call them species is like calling dress-parade cadets "soldiers." I have heard this definition of a soldier-"one that has stood." It is easy to trick out a group of boys to look like soldiers, but you can not define them as such until they have "stood." A greenhouse variant is easily secured; with some plants excessive variability is itself a specific character. But temporary variations have no taxonomic value. A form is not a species until it has "stood."

The production of species from ancestral forms is a process which has striking analogies to the formation of words from older roots. It is easy to make a new word, as a variant or mutation from an older root, or even to create one without a root. But these creations are not words. They do not get into the dictionaries until they have "stood." They must have held their own in the gauntlet of speech which every word has to run. The new words may look as good as old ones. Riley's "gems that laugh hysteric lights, the glittering quespar, guenk and pleocynth," sound technical enough, but these are freaks of the poet, not real words. Being artificial and unreal they are not actual words, never having "stood" in the linguistic struggle for existence.

\section{DAVID STARR JoRDAN}

\section{THE TEACHING OF EVOLUTION}

READERS of Professor Pickett's article on "The Teaching of Evolution"1 will agree that "the teaching of science, particularly of biology or related subjects, in the high school is the chief area of stress." The teaching of introductory biology demands great tact, and, of course, not all teachers have tact. However, the responsibility for the conflict between religious teaching and scientific teaching can not be placed on those teachers.

Opposition to the doctrine of evolution by Mr. Bryan and those of similar views is not opposition to what Professor Pickett calls theories of evolution. It is opposition to the doctrine of evolution in any form whatever. The dispute between Neo-Darwinian and NeoLamarkian does not interest them except as cause for encouragement. To them Darwinism means evolution, nothing more. With an unbending mind they recognize disagreement between the plain literal biblical account of creation and the doctrine of evolution. They embrace the former and are unable to accept any of the compromises that have been offered.

1 Scrence, September 15, 1922, LVI, 298. 
The biologist is ready to receive new evidence but it is difficult to see how he can trim known facts to suit the opposition. However, science holds the key to the situation. The key is evolution itself, the evolutionary interpretation of history, especially the religious and literary history of the Hebrew people. This rather than biology would quickly become the storm center if it were taught in our high schools. It can not be done at present, but when historical science percolates more thoroughly into the Sunday schools the opposition to the teaching of evolution will dissolve. In the mean time the biologist bears the brunt of opposition because his pupils (or their parents) are not prepared for his message. He has to offer a new interpretation of life, a new basis of ethics, which is in opposition to tradition. $\mathrm{He}$ is usually better fitted to discuss and to appreciate the beliefs of the non-scientifically trained man than is the latter to discuss the scientific view, because the biologist has not always been a scientist. The scientist is a trained seeker for truth. His past beliefs, experiences and mental conflicts form a valuable intellectual background. The non-scientifically trained person can not claim a similar appreciation of the scientific view. The biologist must have something of the spirit of a missionary and if necessary that of a martyr.

\section{J. Howard Brown}

\section{Princeton}

\section{TINGITIDAE OR TINGIDAE}

Is his discussion of this family name in a recent number of SCIENCE, Dr. W. J. Holland has provided us with an excellent review of the philological and nomenclatural facts in the matter, but he fails to mention certain items which have a bearing on the question.

Some years ago in a review of Van Duzee's "Check List of the Hemiptera" (Psyche, XXIII: 129, 1916), I stated very briefly my reason for adopting the form Tingidce and it seems necessary to bring forward this argument again to the end that nothing pertinent be overlooked in reaching our decision. In connection with his original proposal of the generie name Tingis, Fabricius ("Systema Rhyngoto- rum," 1803, p. 124) himself uses the genitive Tingis in a foot-note, and accordingly we must adopt the family form Tingida, unless we can prove that the author was in error regarding the genitive form of his own generic name. When I first considered the question I took into account the facts which Dr. Holland adduces, and I came to the conclusion that we can not be sure that Fabricius did in fact adopt the Greek word Tiryss, the name of a city; on the contrary, his use of the genitive Tingis shows us that he considered the word his own and indicates what its Latin declension should be.

Until this argument is disposed of I shall consider it necessary to use the form Tingida, as proposed by Westwood in 1840 .

\section{H. M. Parshley}

\section{Smith College}

\section{THE VACUUM TUBE AMPLIFIER IN SCIENTIFIC WORK}

THE amplification of sound by means of the triode vacuum tube has now passed on from its application to wired and wireless telephony to a means of aiding those of deficient hearing. Its effectiveness is so great that it promises to be to the partially deaf as great a boon as glasses to those optically defective. The use of the amplifier is sure to expand rapidly in this field, although it will be somewhat impeded by its expense.

The purpose of this note, however, is to call attention to the application or applicability of a sound magnifier in various fields of scientifie work and industry:

1. For detecting distant underground operations as in mine reseue or military work.

2. Detecting the approach of a boat, train or automobile before it comes in sight.

3. Detecting the approach of a storm.

4. As a parallel instrument to the binocular prism glasses of the ornithologist, to detect bird songs too far to be heard distinetly or at all. It is particularly useful in deteeting the higher notes that do not carry far and in observing nocturnal migration.

5. To aid the hunter in detecting sounds of distant game.

6. In conversation from vessel to vessel or station to station at shouting distance and a little further. 